\title{
ROMS-NPZDモデルを用いた黒潮域における 中規模海洋変動と低次生産の解析
}

\author{
内山 雄介 1 ・鈴江 洋太 ${ }^{2} \cdot$ 山崎 秀勝 3 \\ 1正会員 神戸大学教授大学院工学研究科市民工学専攻（广657-8501兵庫県神戸市灘区六甲台町1-1） \\ E-mail: uchiyama@harbor.kobe-u.ac.jp \\ 2 学生会員 神戸大学大学院工学研究科市民工学専攻（ T657-8501 兵庫県神戸市灘区六甲台町 1-1） \\ 3 非会員＼cjkstart東京海洋大学教授大学院海洋科学技術研究科（广108-8477 東京都港区港南 4-5-7）
}

\begin{abstract}
黒潮域での中規模海洋変動に対する一次生産の応答を評価するために, 領域海洋循環モデルROMS と NPZD 型生態系低次生産モデルをカップリングしたROMS-NPZDモデルを用いて, 中規模渦解像・サブメソスケ 一ル渦許容気候值解析を行った。太平洋沿岸黒潮域（遠州灘沖）での一次生産は黒潮に伴う中規模渦の影 響を強く受けるが，流軸北側の沿岸域では低気圧性中規模渦による局所的な湧昇によって一次生産が活発 に起こるのに対して, 表層渦運動エネルギーがより強い黒潮流軸周辺では渦輸送によって栄養塩が表層か ら下方へ輸送され，表層での一次生産が抑制される。黑潮続流域（房総半島沖）の表層では下方への栄養 塩渦輸送は見られず，黒潮域と黒潮続流域では低次生産への中規模渦の影響は大きく異なっている.
\end{abstract}

Key Words : ROMS-NPZD model, Kuroshio, mesoscale eddy, subduction, eddy nutrient flux

\section{1. はじめに}

内湾域や沿岸域は，河川からの栄養塩の流入や沿岸湧 昇などによって栄養塩が海洋表層に供給されるため, 表 層付近で活発な一次生産が生じ，富栄養な海域となるこ とが多い，それに対して，外洋における一次生産は沿岸 域に比べて一般に極めて低い. 例えば，我が国の太平洋 沿岸を東進する黒潮暖水は栄養塩に乏しい. しかしなが ら，黒潮は陸棚周辺に強いフロントを形成し，そこでは 温度風平衡に伴う鉛直シアによる鉛直混合，中規模渦に よる湧昇・沈降，フロントに沿った表層水のsubduction などが生じるため, これらのメカニズムによって表層へ の栄養塩の供給や, 低塩分・高酸素水の下方輸送が起こ る. その結果, 黒潮フロント域は貧栄養な外洋の中でも 比較的高い生産性を維持する役割を果たしていると考え られ，黒潮続流域などは好漁場となっている。

さらに, 海洋生態系は大気中の二酸化炭素を吸収・固 定するため, 地球温暖化などの気候変動の緩和に大きく 貢献していると考えられている，UNEPによれば，全生 物が吸収する炭素のうち約55 \%はプランクトンなどの 海洋生物によって吸収されると報告されている11。 その ため, 沿岸域や内湾域のみならず, 外洋における一次生 産を定量的に評価することは，そこに接続する沿岸域の 水質生態環境だけでなく, ブルーカーボンの生成を通じ て地球環境問題を考える上でも重要な課題である.
そこで本研究では，黒潮域での中規模海洋変動に対す る生態系の一次生産の応答を定量的に評価することを目 的とし，領域海洋循環モデルROMSとNPZD型の生態系低 次生産モデルをカップリングしたROMS-NPZDモデルを 用い，黒潮・黒潮続流域を含む本州太平洋沿岸を対象之 した中規模渦解像・サブメソスケール渦許容気候值解析 を行った. 本報では, 特に黒潮に伴う中規模渦・サブメ ソスケール渦による局所的な湧昇による栄養塩の供給と, 黒潮フロント域での渦運動に伴う栄養塩のsubductionに 代表される鉛直輸送が一次生産に及ぼす影響を評価した ので，その結果を報告する.

\section{2. 解析モデル}

\section{(1) 流動モデル}

本研究では，黒潮大蛇行等の間欠的な個別イベントで はなく, 平年值としての黒潮と一次生産の関係を解析す るため, 流動・生態系モデルともに気候值（climatology） 解析を行う。流動モデルでは, JCOPE2海洋再解析デー 夕2)（水平解像度約 $10 \mathrm{~km}$ ) の月平均気候值を初期条 件・境界条件として, 領域海洋循環モデルROMSを用い た1-way offlineネスティングにより解像度3 kmのROMS-L1 領域へとダウンスケーリングを行う（図-1，表-1）。海 上風応力には気象庁GPV-GSMの日平均気候值を, その他 の海面フラックスにはCOADS05の月平均気候值を与える. 


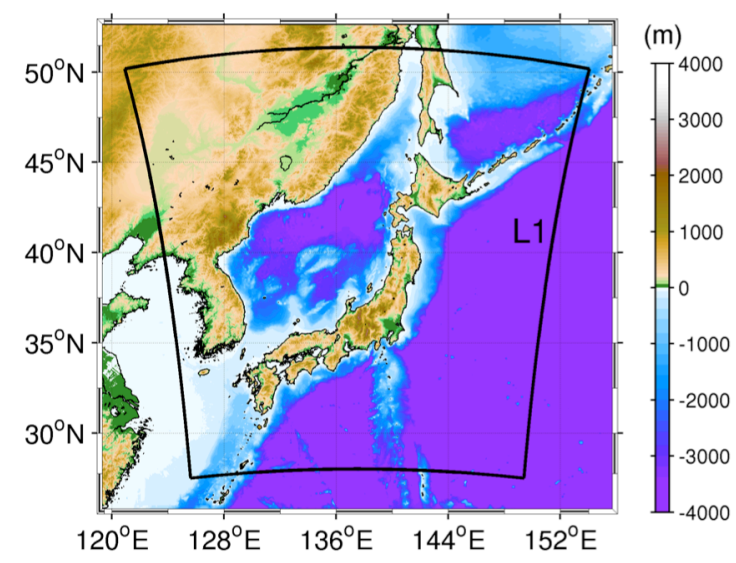

図-1 ROMS-L1 計算領域（黒枠）と水深分布（カラー）.

表-1ＲOMS-L1モデル計算条件

\begin{tabular}{|c|c|}
\hline 格子数 & $784 \times 864 （ \times$ 鉛直 32 層） \\
\hline 水平空間解像度 & $3 \mathrm{~km}$ \\
\hline 海上風応力 & JMAGPV-GSM（日平均気候值） \\
\hline 海面フラックス & COADS（NOAA, 月平均気候值） \\
\hline 海底地形 & JEGG500 + SRTM30 \\
\hline 境界条件 & JCOPE2 再解析值（月平均気候值） \\
\hline 緩和用 SST & Pathfinder-AVHRR（月平均気候值） \\
\hline
\end{tabular}

さらに，黒潮流路の再現性を向上させるためにTS Nudging $\left(\gamma=1 / 20\right.$ day $^{1}$; 詳細は内山ら 3,4 を参照 $)$ を適用する。 なお，同一グリッドで同様の設定を用いたsynoptic計算 結果から, 対象海域の3次元海洋構造を良好に再現可能 であることを確認済みである4)。計算開始後 1 年間はス ピンアップ期間とし，2年目を解析対象期間とする.

\section{(2) 生態系モデル}

Fashamら5による窒素ベースの低次生産NPZDモデルを 用い, 北太平洋海域向けに各種パラメータの調整を行っ た. 本NPZDモデルでは, 栄養塩 $\left(\mathrm{N}\right.$ : 硝酸塩 $\mathrm{NO}_{3}$, アン モニウム塩 $\left.\mathrm{NH}_{4}{ }^{+}\right)$，植物プランクトン $(\mathrm{P})$ ，動物プラ ンクトン（Z），デトライタス（D）の5要素を考慮する. Gruberら句を参考に，初期・境界条件にはWorld Ocean Atlas 2015 （WOA）による $\mathrm{NO}_{3}$-3次元分布の季節平均気候 值（深層は年平均気候值）, MODIS/Aquaによる海表面 Chl.a月平均気候值に対してMorel \& Berthos》による鉛直分 布モデルを適用して得られる3次元分布, Chl.aに比例さ せた動物プランクトン濃度分布を与え, 初期デトライタ ス，アンモニウム塩はゼロとした気候值計算を行う。な お，低解像度のWOAでは沿岸域での $\mathrm{NO}_{3}$-分布を表現でき ないため, 水深 $500 \mathrm{~m}$ 以浅の海域に対しては水深 $500 \mathrm{~m}$ で の $\mathrm{NO}_{3}$ 鉛直分布を線形内挿したものを初期分布として与 えた. 初期条件に含まれる不確実性は1年間のスピンア ップ期間中に解消され，2年目の本計算では各生態系変 数は初期条件によらずに内因的な物質収支にしたがって 変動することを確認している。

\section{3. 海洋表層における水平構造}

\section{（1）黒潮域・黒潮続流域の乱流構造}

西岸境界流である黒潮は, 流路周辺に中規模渦やサ ブメソスケール渦を伴いながら太平洋沿岸域を東進する. 遠州灘沖における物質分散は，黒潮と海岸線の間に間欠 的に出現する中規模渦の影響を強く受けることが報告さ れている8)。また, 北太平洋中緯度海域（米国西海岸沖） では, 中規模変動の強度を示寸表層渦運動エネルギー

（EKE）が高い領域で表層での一次生産が抑制される事 例が報告されている9，そこでまず，モデルによる冬季， 夏季の典型的な表層無次元相対渦度（鉛直成分, 日平均 值）を図-2に示す．冬季には微細なサブメソスケール渦 が多いのに対し，夏季は中規模渦が卓越するものの，大 局的にはいずれの季節も蛇行する黒潮流路に対して北に 正，南に負の渦度がほぼ軸対称に分布している。 また， サブメソスケール渦は黒潮に伴う密度フロントが存在す る黒潮流軸直上ではなく, 流軸から南北方向に約1度離 れた位置に多く発達しているが，流軸と地形に挟まれた 海域での渦のサイズは外洋の渦と比較すると大きい.

季節変動成分（周期90日以上）を除去した年平均の 表層EKEを見ると, 黒潮・黒潮続流の流路周辺に高い EKEが分布している（図-3 (a)）。また，遠州灘沖を拡大 すると，黒潮流軸と海岸線の間には御前崎（CO）の約 $100 \mathrm{~km}$ 南に周囲より水位が低く, 反時計回りの低気圧 性冷水渦が，また潮岬（CS）の東側には周囲より水位が 高く, 時計回りの高気圧性暖水渦が形成されている（図 -3 (b)） . 御前崎沖に形成される低気圧性中規模渦によ る局所的な湧昇は, 表層への栄養塩供給を促進し, 一次 生産に大きな影響を与えているものと推察される.

\section{（2）表層Chl.a濃度分布}

次に, ROMS-NPZDモデルの精度検証の一例として, 衛星データ（MODIS/Aqua）と本モデルによる表層Chla 濃度分布を比較する（図-4）。用いたNPZDモデルは, 同種の様々な生態系モデルの中でもかなり簡素なモデル であるが，表層でのChl.a濃度分布の再現性は比較的良好 であると考えられる. 例えば, 太平洋沿岸域でのChl.a分 布パターンや，全体的な濃度の值などについて，観測值 から大きく逸脱していない. しかしながら，モデルによ るChl.aは，浅海域や内湾，瀬戸内海や黄海などの閉鎖性 の強い海域を中心に過小評価傾向にある.この原因は, 揚子江，鴨緑江，アムール川，国内一級河川などからの 流入に代表される陸域起源の栄養塩供給を考慮していな いためである. 反対に，黒潮続流の北部から北海道東岸 沖などの高緯度域ではモデルのChl.aは過大評価気味であ るが，これは北太平洋亜寒帯循環の影響範囲における鉄 制限に起因する基礎生産性低下10)がモデル内で考慮され 


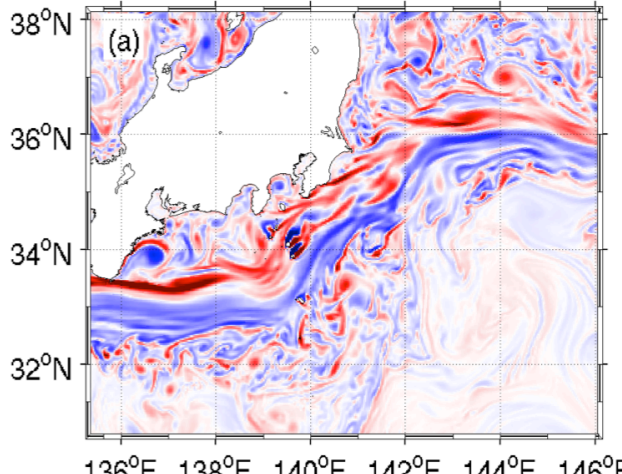

$136^{\circ} \mathrm{E} \quad 138^{\circ} \mathrm{E} \quad 140^{\circ} \mathrm{E} \quad 142^{\circ} \mathrm{E} \quad 144^{\circ} \mathrm{E} \quad 146^{\circ} \mathrm{E}$

図-2 海表面における無次元相対渦度 $(\zeta / f)$ の日平均

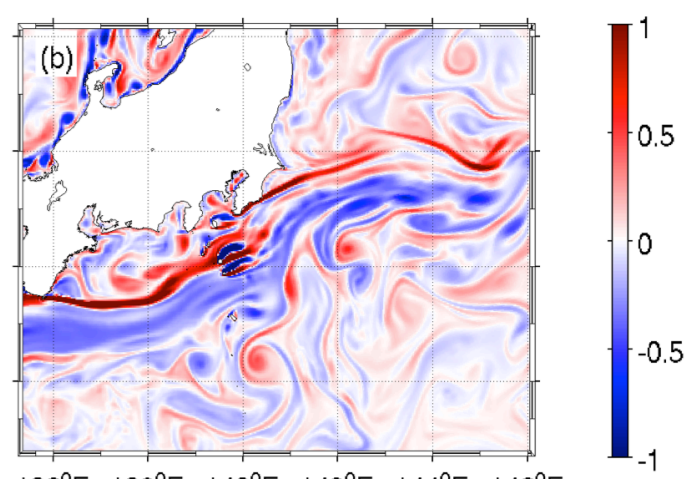

$136^{\circ} \mathrm{E} \quad 138^{\circ} \mathrm{E} \quad 140^{\circ} \mathrm{E} \quad 142^{\circ} \mathrm{E} \quad 144^{\circ} \mathrm{E} \quad 146^{\circ} \mathrm{E}$
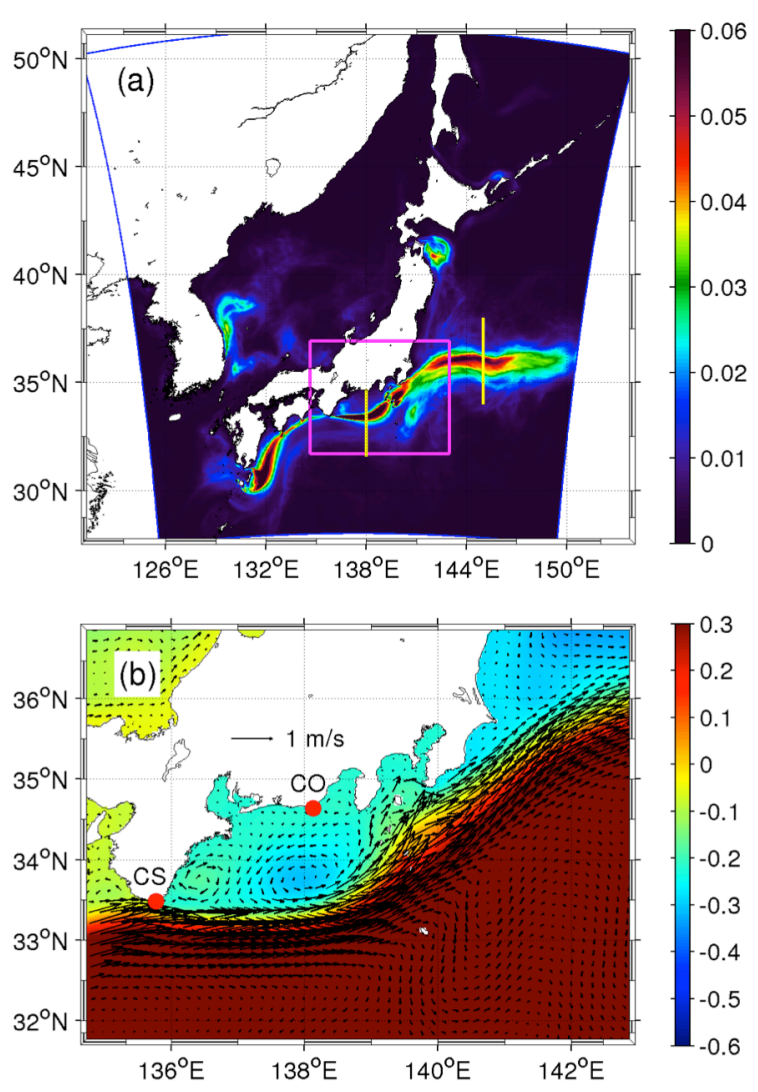

図-3（a）季節変動成分を除去した海洋表層渦運動エネ ルギーEKE $\left(\mathrm{m}^{2} \mathrm{~s}^{-2}\right) ，$ （b）海面高度（SSH，カラ 一：m）および表層流速ベクトル $\left(\mathrm{m} \mathrm{s}^{-1}\right)$. いずれ も年平均気候值（（a）のマゼンタ枠は（b）の領域 を示しており，黄線はそれぞれ図-5～10で用いる東 経 138 度（黒潮域），145 度（黒潮続流域）に沿つ た検査線を示す。

ていないことなどに起因する. これらの問題は, 浻岸域 への陸水影響を考慮し, 鉄収支を含むより複雑な物質循 環モデルの導入で解決されると考えており，今後の検討 課題としたい. 本研究では平均流や渦運動に伴う栄養塩 輸送とそれに対する生態系の応答をできるだけシンプル な枠組みに基づいて考察することを志向することとする. 黒潮周辺海域での生態系の応答を検討寸るために御前 崎沖の遠州灘（以降，黒潮域と呼称する）に着目すると, 表層Chl.aは黒潮流軸を境界として沿岸域と外洋で大きく

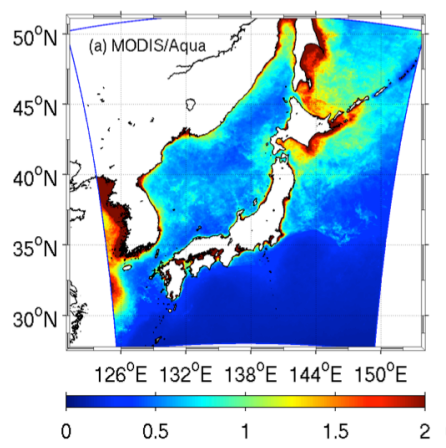

(b) 夏季 $(7 / 30)$.

図-4 表層 Chla 濃度分布 ( $\mu$ g L L -1$)$. (a) 人工衛星データ (MODIS/Aqua)，（b）ROMS-NPZD モデル計算結果によ る. いずれも年平均気候值.

異なっている，低気圧性渦が形成される黒潮流路 (SSH 勾配が大きい強流域）北側の沿岸域では（図-3 (b)）, 渦に伴う局所的な湧昇による表層への栄養塩の供給によ って活発な一次生産が惹起され，高濃度のChl.aが表層に 分布している。 反対に, EKEが高い黒潮流路周辺では

（図-3 (a)），Chl.a濃度はむしろ著しく低下している. ところが, 同じくEKEが高い黒潮続流域 (房総半島沖) では，黒潮流軸付近の表層Chl.aはあまり低下しない傾向 にあり，同じ黒潮の影響海域でも遠州灘沖と房総半島沖 では一次生産の応答に有意な差があることが分かる.

\section{4. 黒潮域・黒潮続流域における鉛直構造}

\section{(1) Chl.a, $\mathrm{NO}_{3}$-の鉛直分布}

黒潮域（遠州灘沖）, 続流域（房総半島沖）での一次 生産応答特性の発生機構を考察するために, 海面下の鉛 直構造を精査する。黒潮と黒潮続流を横断するように東 経138度，145度上に検査線を設定し（図-3 (a)黄線）， 黒潮流軸上および南北に1度（約110 km）ずつ離れた2

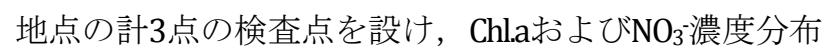
を求めた（図-5, 図-6）。ただし，黒潮流軸位置は黒潮 の主流部が位置する水深50 mにおいて主流速の年平均 值が最大となる場所と定義している. 黒潮域, 続流域と もに, 流軸より北に1度離れた地点では中深層以下に分 布する栄養塩の表層方向への供給が盛んに起こっており， 

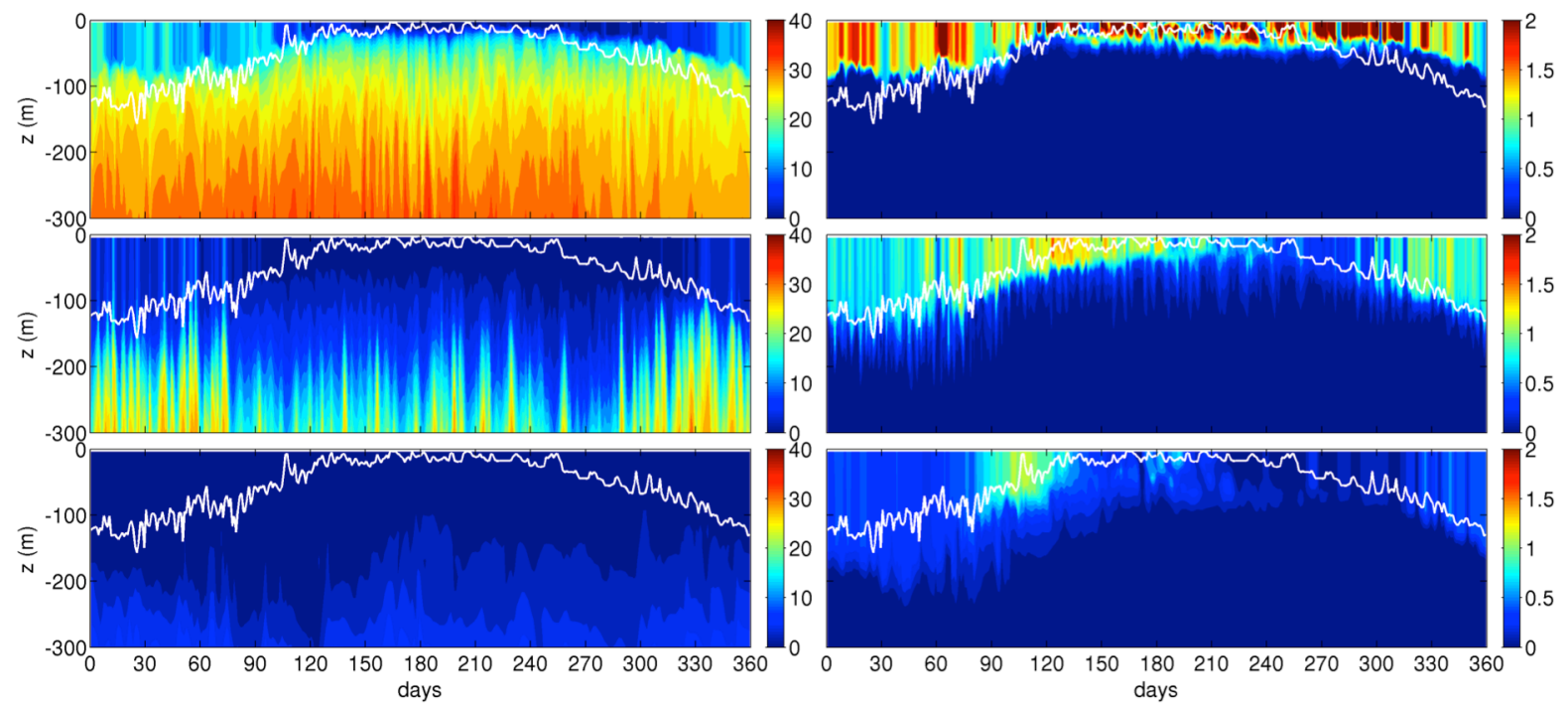

図-5 黒潮域（遠州灘沖）：東経 138 度ライン（図-3 (a) 左黄線）上の各検査点における（左） $\mathrm{NO}_{3}$ 濃度（mmolN mg-1），

(右) Chl.a 濃度 $\left(\mu \mathrm{g} \mathrm{L}^{-1}\right)$ の Hovmöller 図. 縦軸 : 水深, 横軸 : 時間. 上から, 黒潮流軸から北へ 1 度, 流軸直上，南へ 1

度離れた地点での結果. 各パネルの白線は各検査点における KPP モデルから推定される混合層深さである.
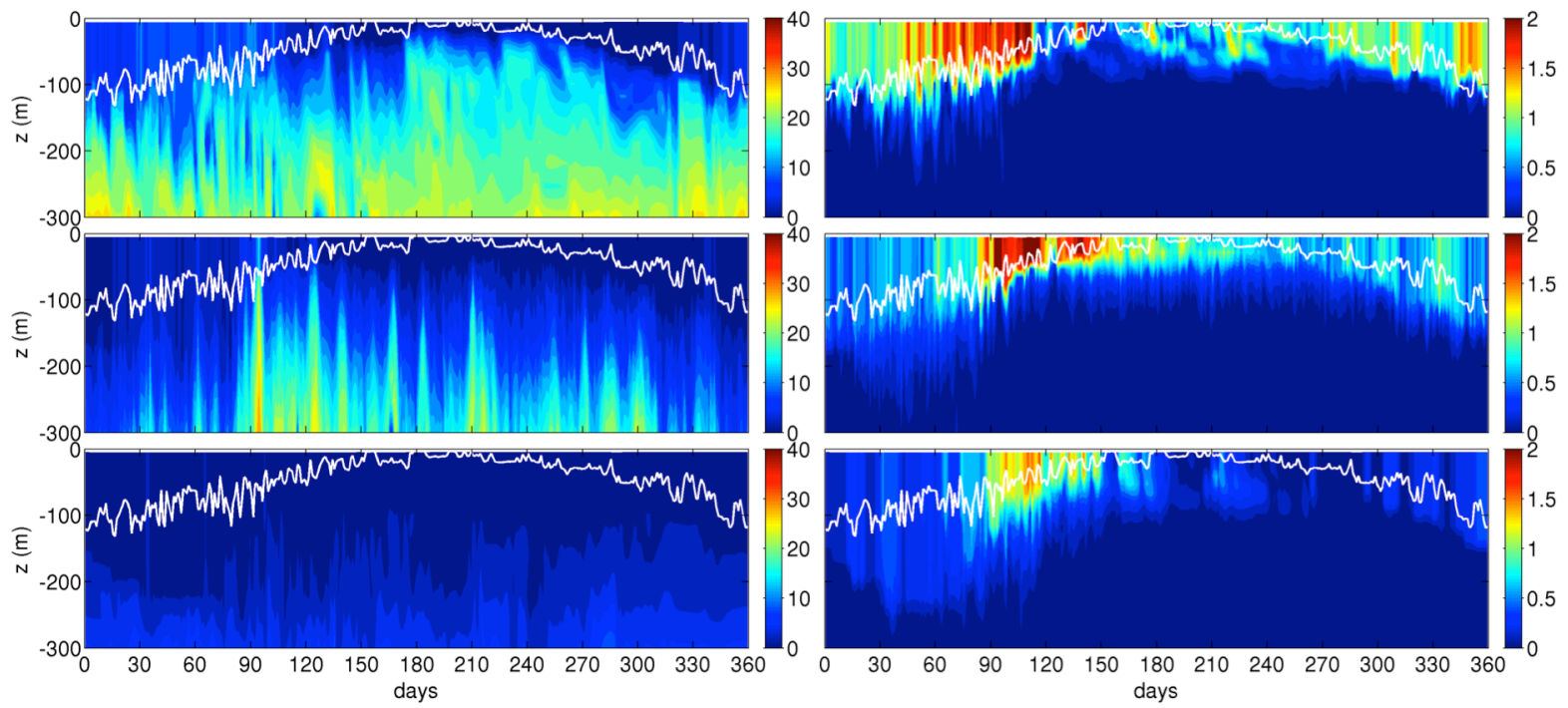

図-6＼cjkstart図-5 と同じ．ただし，黒潮続流域（房総半島沖）：

: 東経 145 度ライン（図-3 (a)右黄線）での結果.

その結果として表層から亜表層のChl.aが増大している.

また，平均 $\mathrm{NO}_{3}$ 濃度の上限值が出現する水深には両海域 に共通して明確な季節変動があり，混合層の消長と連動 して寒冷期には深く（黒潮域では水深約 $100 \mathrm{~m}$, 続流域 では約 $200 \mathrm{~m}$ ），温暖期には浅く（同じく20 m， $50 \mathrm{~m}$ 程 度）なっている. Chl.aの極大值は，寒冷期では混合層上 部の表層全体で生じているのに対して，温暖期では混合 層下端周辺の亜表層で生じている．また，温暖期に比べ て寒冷期により深くまで高濃度のChl.aが分布している.

流軸上，南側検査点と南下寸るにつれて中深層からの 栄養塩供給は小さくなり，それに伴ってChl.a濃度も低下 する. 南側2点での季節変動傾向は北側検査点と基本的 には同様であるが，4月，5月を中心に春季ブルーム (大増殖) に対応するChl.aの季節的な増加が発現してお り，その程度は黒潮続流域のほうが顕著である，その影
響を受けて続流域でのChl.aは平均的に黒潮域よりも高く なり,また，同期間ではChl.a変動と連動して顕著な栄養 塩上昇が間欠的に生じている. この傾向は南側検査点で も見られるが，その程度は流軸上よりもかなり弱い。

シンプルな本NPZDモデルでは，一次生産は $\mathrm{NO}_{3}$-供給 量にほぼ規定されるため, 中深層からの上向き栄養塩フ ラックスが表層・亜表層におけるChl.a分布の形成に直接 的に関与していると考えられる. 特に，両海域では黒潮 流路変動や，中規模渦・サブメソスケール渦が活発に生 じるため，その影響を受けるChl.a， $\mathrm{NO}_{3}$-濃度は数日周期 で変動している，そこで以下では，季節変動（周期 90 日）より短周期の変動を渦成分と定義し，渦に伴う栄養 塩フラックスによる表層への栄養塩供給過程に関する解 析を行う。なお，図-2に見られた渦サイズの季節変化な どによる影響については別の機会に紹介したい. 

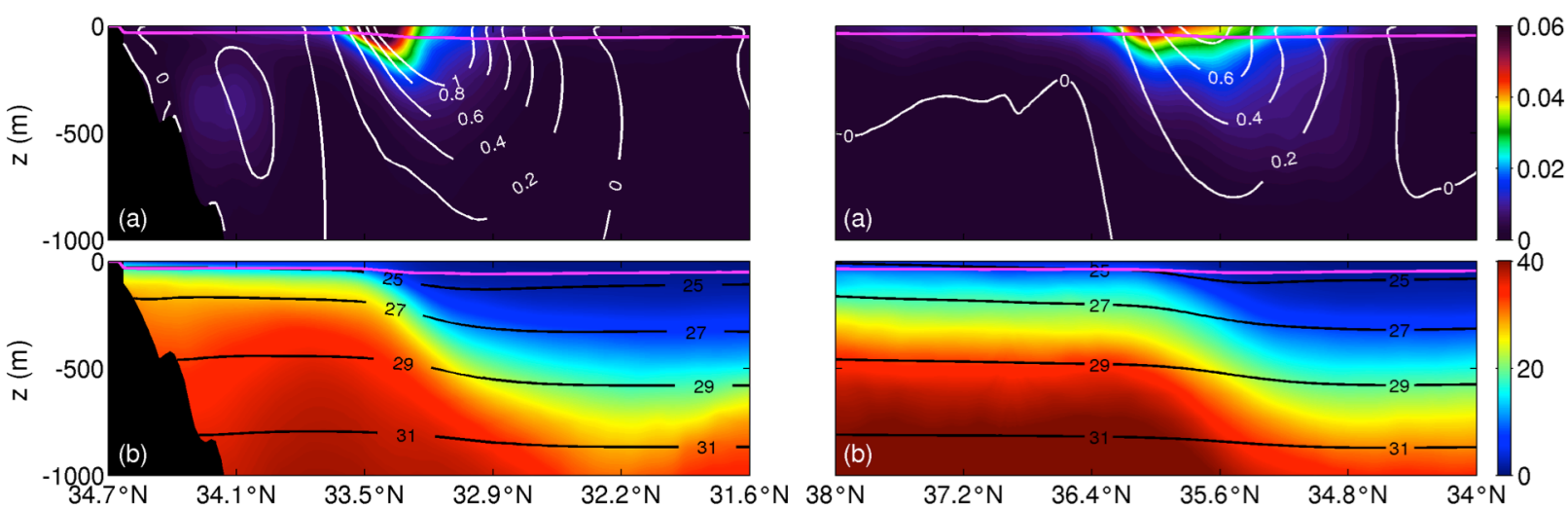

図-7 東経 138 度ライン（左），東経 145 度ライン（右）における（a）カラー：洞運動エネルギーEKE $\left(\mathrm{m}^{2} \mathrm{~s}^{-2}\right)$, 白コンター： 平均流速 $\left(\mathrm{m} \mathrm{s}^{-1}\right)$ の断面直行成分（流下方向を正），（b）カラー： $\mathrm{NO}_{3}$-濃度 (mmolN mg-1)，黒コンター：ポテンシャル密 度 $\left(\mathrm{kgm}^{-3}\right)$, 各パネルのマゼンタ線は KPP モデルによって推定された混合層深さを示している. いずれも年平均気候值.

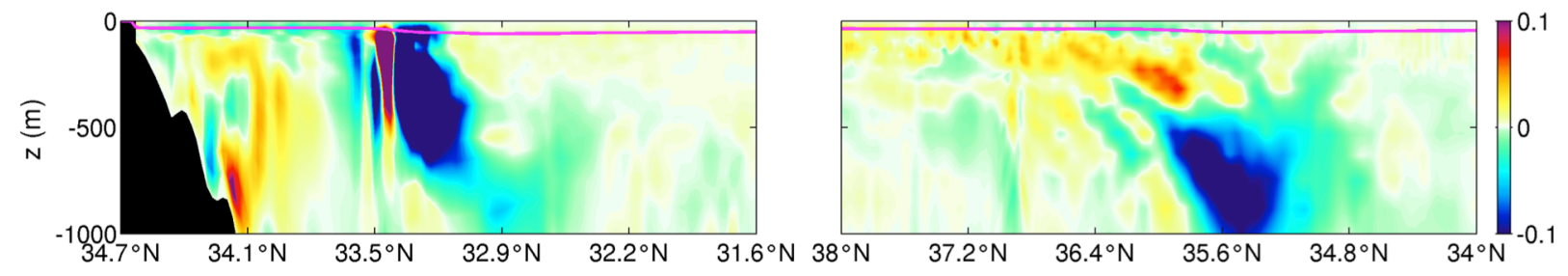

図-8 東経 138 度（左），東経 145 度（右）ラインにおける鉛直 $\mathrm{NO}_{3}$-フラックス渦成分（ $\mu \mathrm{molNmg}^{-1} \mathrm{~ms}^{-1}$. 鉛直上向き正）。

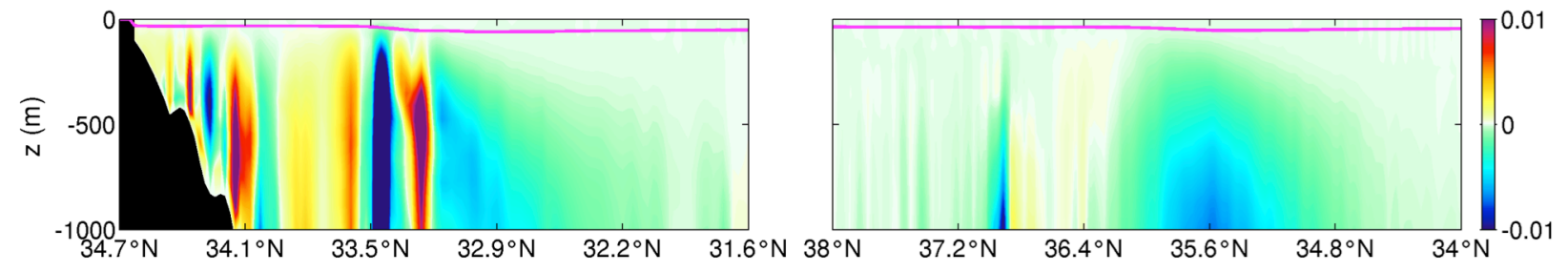

図-9 図-8 と同じ.ただし，鉛直 $\mathrm{NO}_{3}$ フラックス季節変動（残差）成分（ $\mu \mathrm{molNmg}-1 \mathrm{~m} \mathrm{~s}^{-1}$. 鉛直上向き正）．
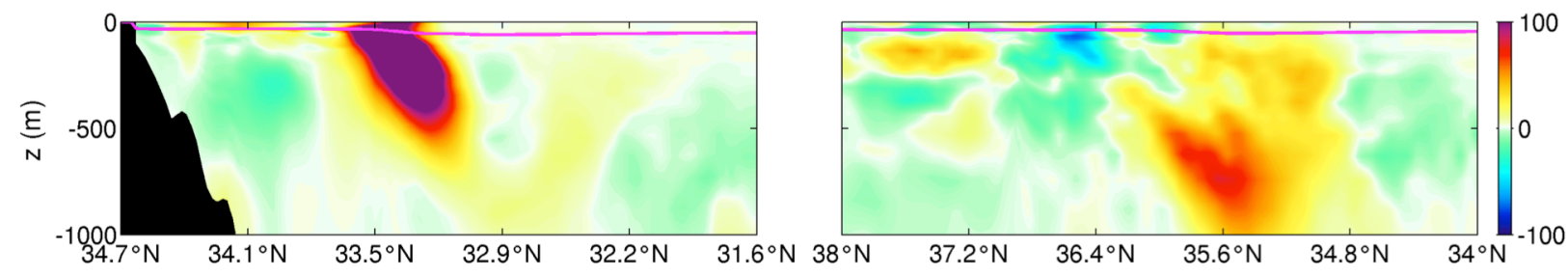

図-10 図-8 と同じ. ただし, 水平 $\mathrm{NO}_{3}$ フラックス渦成分 $\left(\mu \mathrm{molNmg-1} \mathrm{ms}^{-1}\right.$. 沖合・南方向正).

\section{(2) 栄養塩輸送に対する渦の影響}

黒潮域，続流域に設定した各検査線断面内の鉛直構造 を比較すると（図-7），黒潮流軸はそれぞれ北緯33度， 35.5度あたりに位置しており, 黒潮流軸に対応して高い EKEが分布している. また, ポテンシャル密度と栄養塩 $\left(\mathrm{NO}_{3}{ }^{-}\right)$の等值線は, 黒潮流軸に対応して沖側で沈み込 んでいる. 特に $\mathrm{NO}_{3}{ }^{-}$の黒潮域, 続流域ともに南側での沈 み込みは顕著であり, $\mathrm{NO}_{3}$ が下方へ輸送されて濃度低下 していることが示唆される. また，このような $\mathrm{NO}_{3}$ の黒 潮域での沈み込みは解像度 2 度のWOAデータには見られ ないことから，黒潮やその流路変動，それらに伴う渦運 動の影響を受けて局所的に形成された分布形と言える.
$\mathrm{NO}_{3}$-輸送に対する渦の影響を定量的に評価するために, 周波数フィルタを用いて各変量をReynolds分解し, $\mathrm{NO}_{3}-$ 濃度と流速 $\mathbf{u}$ の渦成分同士の相関項を求め, それらを年 平均し，鉛直 $\mathrm{NO}_{3}$-フラックスの洞成分を求めた（図-8）。 東経138度ラインでは, 北緯33.5度, 水深500 $\mathrm{m}$ 以浅に強 い負（鉛直下向き）の $\mathrm{NO}_{3}$ フラックスが見られ，黑潮の 主流部に沿うようにsubductionが卓越することが明示さ れている. また，負值の北側上部の混合層直下に正值が 分布していることから，流軸北部覀表層の $\mathrm{NO}_{3}$-が混合層 底部に上昇し, それがturnoverして南側下層へと輸送さ れ, 流軸から南側の表層 $\mathrm{NO}_{3}$-が急減しているものと理解 される. 東経145度ラインでも定性的には同様の傾向が 見られるが，全体的に值は小さく，流軸北側の水深 400 
$\mathrm{m}$ 以浅の亜表層に正值が広く分布し，負值は正值の下部 に相当する流軸南側の水深400 $\mathrm{m}$ 以深に分布している. なお，鉛直 $\mathrm{NO}_{3}$-フラックス季節変動（渦成分との残差） 成分は両海域ともに渦成分より 1 桁以上小さく, $\mathrm{NO}_{3}-$ の 鉛直輸送には渦成分の寄与が圧倒的に大きい（図-9）.

また, 両検査線断面内の水平 $\mathrm{NO}_{3}$-フラックス渦成分を 見ると（図-10），subductionが生じる領域でともに正值

（南方向）を取ることから，黒潮域では沿岸湧昇や低気 圧性渦によって表層に供給された栄養塩は黒潮フロント に沿って速やかに沖合下方に輸送され，流軸および南側 海域表層での一次生産が強く抑制されていると解釈され る. 一方, 続流域でのsubductionと南方向輸送は黒潮底 部付近の水深500 m以深の中深層で活発に生じており, 北太平洋中層水に栄養塩を供給している. 続流域表層に 存在する $\mathrm{NO}_{3}$-の下方への輸送は相対的に小さため, 一次 生産の抑制効果も黒潮域より小さくなると考えられる.

\section{6. おわりに}

本研究では, ROMS-NPZDモデルを用いて黒潮域（遠 州灘沖），黒潮続流域（房総半島沖）での中規模海洋変 動が低次生産に及ぼす影響について評価した。黒潮-海 岸間に形成される低気圧性の中規模渦に伴う局所的な湧 昇によって，遠州灘沿岸域では続流域北部よりも高い一 次生産が維持されていることを示した. 両海域ではとも に黒潮に伴う中規模渦活動が活発であるにも関わらず, 一次生産への影響は大きく異なっていた。渦による栄養 塩輸送を定量的に評価した結果, 黒潮フロントに沿って 下方に栄養塩が輸送されることで黒潮流軸および南側海 域表層での一次生産に影響を与えていることが明らかと なった。

謝辞：本研究は，JST-CREST「海洋生物多様性および生 態系の保全・再生に資する技術基盤の創出」領域（代表
者：山崎秀勝）および科学研究費補助金（15H00977, 15H04049, 代表 : 内山雄介）の援助を受けた.

\section{参考文献}

1) Nellemann, C., Corcoran, E., Duarte, C. M., Valdés, L., De Young, C., Fonseca, L, and Grimsditch, G. (Eds), Blue Carbon. A Rapid Response Assessment, United Nations Environment Programme, GRIDArendal, Birkeland TrykkeriAS, Norway, 78p., 2009.

2) Miyazawa, Y. and coauthors: Water mass variability in the western north Pacific detected in 15-year eddy resolving ocean reanalysis, $J$. Oceanogr., Vol. 65, pp.737-75, 2009.

3) 内山雄介, 石井翔大, 宮澤泰正 : JCOPE2-ROMS 多段 ネスティングによる黒潮続流域でのダウンスケーリ ング効果の検証, 土木学会論文集 B2（海岸工学）, Vol. 68, No. 2, pp. I_436-I_440, 2012.

4) 内山雄介, 神吉亮佑, 高野祥子, 山崎秀勝, 宮澤泰正 : 海面高度計およびArgoデータに基づく 3次元密度推定值を 同化させた海洋流動モデルの再現精度について，土木学 会論文集B3（海洋開発）,Vol.71,No.2,pp.I_365-I_370,2015.

5) Fasham, M. J. R., H. W. Ducklow, and S. M. McKelvie: A nitrogenbased model of plankton dynamics in the oceanic mixed layer,J.Mar. Res., Vol.48, pp.591-639, 1990.

6) Gruber, N. and coauthors: Eddy-resolving simulation of plankton ecosystem dynamics in the California Current System, Deep-Sea Res. I,Vol.53,pp. 1483-1516, 2006.

7) Morel, A. and J.F. Berthon: Surface pigments, algal biomass profiles, and potential production of the euphotic layer: Relationships reinvestigated in view of remotesensing applications, Limnol. Oceanogr., Vol. 34, pp. 1545-1562, 1989.

8) 内山雄介, 鈴江洋太, 小硲大地：瀬戸内海および遠 州灘沿岸域における陸域起源物質分散の季節変動特 性について, 土木学会論文集 B1 (水工学) , Vol.72, No.4, pp. I_949-I_954, 2016.

9) Gruber, N., Z. Lachkar, H. Frenzel, P. Marchesiello, M. Munnich, J. C. McWilliams, T. Nagai, and G.-K. Plattner: Eddy-induced reduction of biological production in eastern boundary upwelling systems, $\mathrm{Na}$ ture Geoscience, Vol. 4, pp. 787-792,2011.

10) Moore, C. W. and coauthors: Processes and patterns of oceanic nutrient limitation, Nature Geoscience, Vol. 6, pp.701-710,2013.

(2016.3.16 受付)

\title{
BIOGEOCHEMICAL RESPONSES TO MESOSCALE OCEANIC VARIABILITY IN THE KUROSHIO REGION ANALYZED WITH A ROMS-NPZD MODEL
}

\author{
Yusuke UCHIYAMA, Yota SUZUE and Hidekatsu YAMAZAKI
}

The Kuroshio is one of the most energetic western boundary currents accompanied by vigorous eddy activity both at meso- and submesoscales which significantly affect biogeochemical productivity in the upper ocean. We examine such processes with a climatological ocean modeling based on ROMS coupled with an NPZD model for the Kuroshio region off Japan. Cyclonic mesoscale eddies develop in the coastal area of Enshu Nada, leading to upward nutrient supply to euphotic zone with promoting active primary production. In contrast, Chl.a is much less prominent around the Kuroshio path where the higher EKE is distributed. The downward eddy-induced vertical nutrient flux occurs at depth beneath the Kuroshio path and the reduction of nutrient consequently takes place. Therefore, a substantial amount of nutrient is removed from the near-surface layer by eddy-driven downward nutrient transport, resulting in suppressing the primary production there. 